\title{
Absorption of Glucose and Maltose in Congenital Glucose-Galactose Malabsorption
}

\author{
P. D. FAIRCLOUGH, M. L. CLARK, A. M. DAWSON, D. B. A. SILK, P. J. MILLA, \\ AND J. T. HARRIES ${ }^{(19)}$ \\ Department of Gastroenterology, St. Bartholomew's Hospital (A. M. D.), London, Liver Unit, King's College Hospital \\ (D. B. A. S.), London, and Institute of Child Health and The Hospital for Sick Children (J. T. H.), Great Ormond
} Street, London, England

\begin{abstract}
Summary
An intestinal perfusion technique has been used to study absorption of glucose from free glucose and the disaccharide maltose in a patient with congenital glucose-galactose malabsorption.

Minimal absorption of glucose occurred from high luminal concentrations of either free glucose $(100 \mathrm{mmole} / \mathrm{liter})$ or maltose (50 $\mathrm{mmole} / \mathrm{liter})$. Glucose diffused into the intestinal lumen during perfusion of a 2 mmole/liter glucose solution.

These observations offer no support for nutritionally important glucose absorption in congenital glucose-galactose malabsorption by either passive diffusion or via a "disaccharidase-related" transport system.
\end{abstract}

\section{Speculation}

In patients with congenital glucose-galactose malabsorption a disaccharidase-related transport system is of no importance as a physiologic mechanism in compensating for the primary defect of monosaccharide absorption.

Dietary carbohydrates are thought to be completely digested to their constituent monosaccharides within the small intestinal lumen or at the brush border surface of the intestinal cells, and the liberated monosaccharides are absorbed either by a sodium-dependent carrier-mediated transport system (glucose and galactose) or by facilitated diffusion (fructose) (5). Recently, however, in vitro experiments with hamster small intestine have suggested that there may be another pathway for the absorption of monosaccharides, which is only accessible to sugars released by hydrolysis of disaccharides at the luminal surface of the intestinal cells $(10,14)$.

In the rare inherited condition of congenital glucose-galactose malabsorption, mucosal histology and disaccharidase activity are normal but the active intestinal transport system for free glucose and galactose is either absent or does not function $(3,8,9)$. This condition offers a unique opportunity to investigate the possible existence in vivo in man of disaccharidase-related transport as a separate entity from the monosaccharide transport system. A perfusion technique has therefore been used to investigate jejunal absorption of glucose from high luminal concentrations of free glucose, and from the equivalent amount of the disaccharide maltose in such a patient.

\section{CLINICAL HISTORY AND DIAGNOSIS}

The patient weighed $3.6 \mathrm{~kg}$ at birth. Profuse diarrhea started at 2 weeks and persisted until glucose and galactose were withdrawn from the diet at the age of 9 months. At the time of study, he was 12 years old and his height and weight were on the 25 th percentile.

He consumes a restricted carbohydrate diet containing approximately $60 \mathrm{mmoles}$ of disaccharide/day (normal intake for age is 200-300 mmoles/day) and uses fructose for sweetening. He now suffers only mild diarrhea and occasional abdominal distention, although dietary indiscretions precipitate exacerbation of symptoms.

The diagnosis was confirmed at the age of 9 as follows: there was no rise in either glucose or serum insulin after oral loads of glucose $(5.5 \mathrm{mmoles} / \mathrm{kg}$ body weight $)$ or lactose $(2.7 \mathrm{mmoles} / \mathrm{kg}$ body weight), and the loads precipitated abdominal distension and watery diarrhea. Blood xylose, however, rose to 1.7 mmole/liter $1 \mathrm{hr}$ after oral xylose, $2.6 \mathrm{mmoles} / \mathrm{kg}$ body weight (normal >1.46 mmole/liter).

The jejunal biopsy was histologically normal and mucosal disaccharidase activity was normal. Mucosal uptake of the amino acid leucine in vitro was normal but sodium-coupled intake of glucose was grossly impaired (18).

\section{INTESTINAL PERFUSION STUDY}

A simple double lumen perfusion system was used to measure jejunal absorption of glucose. The following solutes, in unbuffered solutions adjusted to $\mathrm{pH} 7.0$ by titration with molar sodium hydroxide and made isotonic with plasma $(288 \mathrm{mOsmol} / \mathrm{kg}$ ) by addition of sodium chloride, were perfused through a $20-\mathrm{cm}$ segment of intestine at a flow rate of $10 \mathrm{ml} / \mathrm{min}: 1)$ maltose, 50 mmoles/liter; 2) glucose, 100 mmoles/liter; and 3) glucose, 2 mmoles/liter.

A 30-min equilibration period was allowed for each solution. Three consecutive 10-min samples of intestinal aspirate were then collected into containers maintained at $4^{\circ}$.

Polyethylene glycol $(2.5 \mathrm{~g} /$ liter $)$ was used as the nonabsorbable marker of water movement. The concentration of polyethylene glycol in the three 10-min collections for maltose was 1.47, 1.48, and $1.49 \mathrm{~g} /$ liter; for $100 \mathrm{mmoles} /$ liter glucose 1.50, 1.52, and 1.55; and for 2 mmoles/liter glucose 1.80 and 1.75. These values indicate that a steady-state existed during perfusion of each of the three sugar-containing solutions. Polyethylene glycol was estimated according to the method of Hyden (7). Glucose was estimated by a hexokinase method (Boehringer Corporation, London). Maltose was hydrolysed using yeast $\alpha$-glucosidase and assayed as free glucose.

The patient and his parent gave fully informed consent to the study procedure which was approved by the local Ethical Committee.

\section{RESULTS}

The results are shown in Table 1. Glucose absorption from the $100 \mathrm{mmoles} / \mathrm{liter}$ glucose solution during the three collection periods was $+4.20,-1.58$, and $-0.33 \mu \mathrm{mol} / \mathrm{min} / \mathrm{cm}$ intestine. The mean of these observations is $+0.76 \mu \mathrm{mol} / \mathrm{min} / \mathrm{cm}$ and is considerably lower than the mean absorption value found in normal adult volunteers $(+35.60 \mu \mathrm{mol} / \mathrm{min} / \mathrm{cm})$ using a similar perfusion technique (16). Water absorption from this solution was -0.35 , -0.34 , and $-0.34 \mathrm{ml} / \mathrm{min} / \mathrm{cm}$ with a mean value of $-0.34 \mathrm{com}-$ 
Table 1. Net glucose and water absorption from the glucose and maltose containing solutions in the patient and control subjects

\begin{tabular}{|c|c|c|c|c|}
\hline \multirow{2}{*}{$\begin{array}{c}\text { Concentration } \\
\text { of perfused } \\
\text { sugar (mmole/ } \\
\text { liter) }\end{array}$} & \multicolumn{2}{|c|}{$\begin{array}{l}\text { Water absorption } \\
(\mathrm{ml} / \mathrm{min} / \mathrm{cm})\end{array}$} & \multicolumn{2}{|c|}{$\begin{array}{l}\text { Glucose absorption } \\
(\mu \mathrm{mol} / \mathrm{min} / \mathrm{cm})\end{array}$} \\
\hline & Patient & Controls & Patient & Controls \\
\hline Glucose (2) & $-0.20^{1}$ & $+0.04(6)^{2,3}$ & -0.55 & $+0.54(6)^{3}$ \\
\hline Glucose $(100)$ & -0.34 & $+0.19(12)^{4}$ & +0.76 & $+35.60(12)^{4}$ \\
\hline Maltose (50) & -0.30 & $+0.17(10)^{4}$ & & $+37.00(10)^{4}$ \\
\hline
\end{tabular}

${ }^{1}-$, net secretion; + , net absorption.

${ }^{2}$ Numbers in parentheses, number of subjects.

${ }^{3}$ Data obtained from children $1-4$ years old, who following intensive investigation were diagnosed as having toddler (nonspecific) diarrhea.

${ }^{4}$ Data from normal adult volunteers $(12,16)$

pared with $+0.19 \mathrm{ml} / \mathrm{min} / \mathrm{cm}$ for the adult controls. Glucose absorption from the $50 \mathrm{mmoles} /$ liter maltose solution was +7.00 , -1.33 , and $-5.83 \mu \mathrm{mol} / \mathrm{min} / \mathrm{cm}$ with a mean of -0.10 $\mu \mathrm{mol} / \mathrm{min} / \mathrm{cm}$, which is again considerably lower than the mean absorption value of $37.0 \mu \mathrm{mol} / \mathrm{min} / \mathrm{cm}$ found in normal adult volunteers (12). Water absorption from this solution was -0.34 , -0.33 , and $-0.22 \mathrm{ml} / \mathrm{min} / \mathrm{cm}$, with a mean value of $-0.30 \mathrm{com}$ pared with +0.17 in the adult controls.

During perfusion of the 2 mmoles/liter glucose solution, glucose was secreted into the lumen $(-0.67$ and -0.42$)$ at a mean rate of $-0.55 \mu \mathrm{mol} / \mathrm{min} / \mathrm{cm}$. As with the other sugar-containing solutions, water was secreted $(-0.18$ and -0.22$)$ at a mean rate of -0.20 $\mathrm{ml} / \mathrm{min} / \mathrm{cm}$ compared with that of "control" children who absorbed water $(+0.04 \mathrm{ml} / \mathrm{min} / \mathrm{cm})$.

\section{DISCUSSION}

We did not feel it was justified to perfuse normal children matched for age and weight for the sake of the present study, and since there is no comparable control data reported in the literature, our results are compared with those of McMichael et al. (12) and Sladen and Dawson (16), who used the same type of perfusion tube to study intestinal absorption of glucose from a wide range of concentrations of maltose and free glucose solutions in adult volunteers. We also considered it unlikely that absorption of glucose and maltose would differ to any significant degree in adults compared with children of an age similar to that of our patient. We do, however, include data in Table 1 from "control" children with "toddler" (nonspecific) diarrhea, for absorption of glucose and water from perfused solutions containing 2 mmoles/liter glucose. The normal adult values of glucose absorption from free glucose and maltose are substantially higher than those observed during perfusion of our patient with congenital glucose-galactose malabsorption. Indeed, as the mean glucose absorption value from the maltose solution was not significantly different from zero, this study provides no support for the existence in vivo in man of a nutritionally important disaccharidase-related pathway for glucose absorption from maltose, and confirms a previous study using a single lumen intubation technique (13). It also seems equally unlikely that there is a disaccharidase-related pathway for glucose absorption from sucrose, since Hughes and Senior (6), using a similar experimental technique in another patient with congenital glucose-galactose malabsorption, failed to demonstrate any significant intestinal uptake of glucose during sucrose perfusion.

As mentioned previously a pathway for absorption of disaccharide-bound monosaccharides, separate from that utilized by free monosaccharide, has recently been demonstrated using hamster small intestine $(10,14)$. These experiments were performed under in vitro conditions; whether or not the failure to demonstrate such a pathway in man under in vivo conditions is due to difference in experimental techniques used, or whether species difference is more important is at present unclear.
In vitro studies of the kinetics of glucose accumulation in a patient with congenital glucose-galactose malabsorption and his family (3) and radioautographic studies in another patient with this condition (17) suggests that the defect is due to a reduced number of normal monosaccharide transporting sites. If this was the case, one would expect a proportionally greater absorption of glucose from low than from high luminal glucose concentrations. In this study glucose in fact appeared in the lumen during perfusion of the $2 \mathrm{mmoles} /$ liter glucose solution in contrast to controls, which suggests that the defect in congenital glucose-galactose malabsorption is more likely to be a complete absence or failure to function of the active carrier for glucose and galactose.

It has recently been suggested that glucose absorption in the rat small intestine occurs by two independent routes (2); one is an active electrogenic pathway, which is saturable and phlorizinsensitive, the other a diffusional pathway which is nonelectrogenic, nonsaturable, and phlorizin-insensitive. Furthermore, it was suggested that this latter diffusional component accounted for $50 \%$ of glucose absorption at high luminal glucose concentrations. The present perfusion data show minimal disappearance of glucose from the intestinal lumen even during $100 \mathrm{mM}$ glucose perfusion, and the lack of change in either blood glucose or plasma insulin after an oral glucose load in the same patient suggests that, in man, passive diffusion of glucose even from high luminal concentrations occurs so slowly that this route is nutritionally unimportant.

Finally, two recent in vivo studies have shown that glucose uptake from the human small intestine is more rapid during perfusion of maltose than during perfusion of equivalent equimolar concentrations of free glucose $(1,4)$. Initially, it seemed that this apparent "kinetic advantage" conferred by maltose on glucose uptake could be explained if, in an analogous way to peptide transport $(11,15)$, proportions of the disaccharide-bound glucose were absorbed by a process separate to that used for transport of the free monosaccharide. Now that two groups of investigators have failed to highlight such a pathway for disaccharide-bound monosaccharide transport in man, this explanation is no longer tenable. A more likely explanation for the above data could be that hydrolysis of maltose, by luminally oriented membranebound disaccharidases, delivers directly to the monosaccharide transport sites a greater concentration of glucose in free solution than can be achieved by random diffusion of free monosaccharide from the bulk phase of the gut lumen.

\section{REFERENCES AND NOTES}

1. Cook, G. C.: Comparison of absorption rates of glucose and maltose in man in vivo. Clin. Sci. Mol. Med., 44: 425 (1973).

2. Debnam, E. S., and Levin, R. J.: An experimental method of identifying and quantifying the active transfer electrogenic component from the diffusive component during sugar absorption measured in vivo. J. Physiol. (Lond), 246: 181 (1975).

3. Elsas, L. J., Hillman, R. E., Patterson, J. H., and Rosenberg, L. E.: Renal and intestinal hexose transport in familial glucose-galactose malabsorption. J. Clin. Invest., 49: 576 (1970)

4. Fairclough, P. D., Silk, D. B. A., Webb, J. P. W., Clark, M. L., and Dawson, A. M.: Submitted to Clin. Sci. Mol. Med. (1977).

5. Gray, G. M. Intestinal digestion and maldigestion of dietary carbohydrates. Ann. Rev. Med., 22: 391 (1971).

6. Hughes, W. S., and Senior, J. R.: The glucose-galactose malabsorption syndrome in a 23 year old woman. Gastroenterology, 68: 142 (1975).

7. Hyden, S.: A turbidometric method for the determination of higher polyethylene glycols in biological materials. K. Lanthr. Hogsk. Annlr., 22: 139 (1955).

8. Laplane, R., Polonovski, C., Etienne, M., Debray, P., Lods, J. C., and Pessaro, B.: L'intolerance aux sucres a transfert intestinal actif: ses rapports avec l'intolerance au lactose et le syndrome coeliaque. Arch. Franc. Pediatr., 19: 895 (1962).

9. Lindquist, B., and Meeuwisse, L. W.: Chronic diarrhea caused by monosaccharide malabsorption. Acta Paediatr. Scand., 51: 674 (1962).

10. Malathi, P., Ramaswamy, K., Caspary, W. F., and Crane, R. K.: Studies on the transport of glucose from disaccharides by hamster small intestine in vitro. I. Evidence for a disaccharidase-related transport system. Biochim. Biophys. Acta., 307: 613 (1973).

11. Matthews, D. M., and Adibi, S. A.: Peptide absorption. Gastroenterology, 71: 151 (1976).

12. McMichael, H. B., Webb, J. P. W., and Dawson, A. M.: The absorption of maltose and lactose in man. Clin. Sci., 33: 135 (1967). 
13. Meeuwisse, G. W., and Melin, K.: Glucose-galactose malabsorption. A clinical study of 6 cases. Acta Pediatr. Scand. Suppl., 188: 14 (1969).

14. Ramaswamy, K., Malathi, P., Caspary, W. F., and Crane, R. K.: Studies on the transport of glucose from disaccharides by hamster small intestine in vitro. II. Characteristics of the disaccharidase-related transport system. Biochim. Biophys. Acta, 345: 39 (1974).

15. Silk, D. B. A.: Peptide absorption in man. Gut, 15: 494 (1974)

16. Sladen, G. E., and Dawson, A. M.: Interrelationships between the absorptions of glucose, sodium and water by the normal human jejunum. Clin. Sci., 36: 119 (1969).

17. Stirling, C. E., Schneider, A. J., Wong, M., and Kinter, W. B.: Quantitative radioautography of sugar transport in intestinal biopsies from normal humans and a patient with glucose-galactose malabsorption. J. Clin. Invest., 51: 438 (1972).

18. Wimberley, P. D., Harries, J. T., and Burgess, E. A.: Congenital glucose-galactose malabsorption. Proc. R. Soc. Med., 67: 755 (1973).

19. Requests for reprints should be addressed to: Dr. J. T. Harries, Institute of Child Health, 30 Guilford Street, London WCIN 1EH, England.

20. This research was supported by the Joint Research Board of St. Bartholomew's Hospital and the National Fund for Research into Crippling Diseases.

21. Received for publication October 31, 1977.

22. Accepted for publication February 24, 1978. 